\title{
Study of pterion and asterion in adult human skulls of north Gujarat region
}

\author{
Umesh P Modasiya ${ }^{1}$, Sanjaykumar D Kanani ${ }^{2, *}$ \\ ${ }^{1}$ Associate Professor, ${ }^{2}$ Assistant Professor, Dept. of Anatomy, GMERS Medical College, Himmatnagar, Gujarat, India
}

*Corresponding Author:

Email: drsanjaykanani@gmail.com

Received: $21^{\text {st }}$ February, 2018

Accepted: $4^{\text {th }}$ July, 2018

\begin{abstract}
Introduction: The floor of the temporal fossa is bounded superiorly by the frontal and parietal bones and inferiorly by the greater wing of the sphenoid and squamous part of the temporal bone. All four bones of one side meet at a around H-shaped sutural junction known as Pterion. Asterion found at the junction of the lambdoid, occipitomastoid and parietomastoid sutures.

Materials and Methods: 110 dry human adult aged skull of unknown sex without any gross pathology or abnormality were studied. Sutural pattern of the pterion was observed on both sides of each skull. The sutural pattern of pterion was classified as per Murphy's criteria, into 4 types - sphenoparietal, frontotemporal, epipteric or stellate. On both sides of each skull, the sutural pattern of the asterion was classified into type I and type II

Result: Sphenoparietal was the most common type of pterion observed, $80.9 \%$ of total pterion. Epipteric was the least common type of pterion observed, $8.18 \%$ of total pterion. Frontotemporal was not observed in any skull. Sphenoparital, stellate and epipteric type of pterion shows bilateral symmetry. Most common type of asterion observed to be type II, found in $91.18 \%$ of total asterion. Bilateral symmetry only found in type II asterion.

Conclusion: Observations of our study may be applicable with other commonly used method like radiological analysis for better prediction of different type of sutural morphology. Knowledge of sutural morphology may helpful for better surgical safety and efficacy.
\end{abstract}

Keywords: Pterion, Asterion, Skull, Suture.

\section{Introduction}

The floor of the temporal fossa is bounded superiorly by the frontal and parietal bones and inferiorly by the greater wing of the sphenoid and squamous part of the temporal bone. All four bones of one side meet at a around $\mathrm{H}$-shaped sutural junction known as Pterion. ${ }^{1}$ Pterion is an important landmark as it overlies the anterior branch of the middle meningeal artery and the lateral fissure of the cerebral hemisphere. ${ }^{2}$ Pterion has been commonly used bony landmark for surgeons in various surgical procedure to approach anterior branch of middle meningeal artery, Broca's motor speech area, insula, lateral cerebral fissure $^{3}$ The Pterion is situated $4 \mathrm{~cm}$ above the midpoint of the zygomatic arch. A hard blow to the side of the head may fracture the thin bones forming the pterion may lead to a damage of the important neurovascular structures lies beneath it. The hematoma formation may compress the underlying cerebral cortex. If middle meningeal vessel hemorrhage not treated may lead to death in a few hours. ${ }^{4}$ Pterion is an important landmark for age and gender determination for anthropologist and forensic expert. According to Broca there are three types of pterion - sphenoparital, frontotemporal and stellate. ${ }^{5}$ Murphy classified pterion into four different types - sphenoparital, frontotemporal, stellate and epipteric types. ${ }^{6}$ (Fig. 1)

Wang et $\mathrm{al}^{7}$ observed two more type of pterion in their study - zygomaticoparital type and zygomatico temporal types.
The asterion is a craniometric point at the junction of the lambdoid, occipitomastoid and parietomastoid sutures. ${ }^{8}$ It has been used as a landmark in lateral approaches to the posterior fossa as it defines the superior limit of bone removal for the craniotomy. Asterion sits over the junction between the transverse and sigmoid sinuses in $81 \%$ of subjects, inferior to it in $15 \%$ and superior to it in $4 \% .^{9}$

\section{Materials and Methods}

Total 110 dry human adult aged skull of unknown sex without any gross pathology or abnormality were studied. The skull was obtained from different medical colleges of north Gujarat. Sutural pattern of the pterion was observed on both sides of each skull. The sutural pattern of pterion was classified as per Murphy's criteria, into 4 types - sphenoparietal, frontotemporal, epipteric or stellate. (Fig. 1). Total 220 pterion was studied.

On both sides of each skull, the sutural pattern of the asterion was observed. The sutural pattern of asterion was classified into 2 types - type I (presence of a sutural bone at asterion) and type II (absence of sutural bone at asterion). Total 220 asterion was studied. 


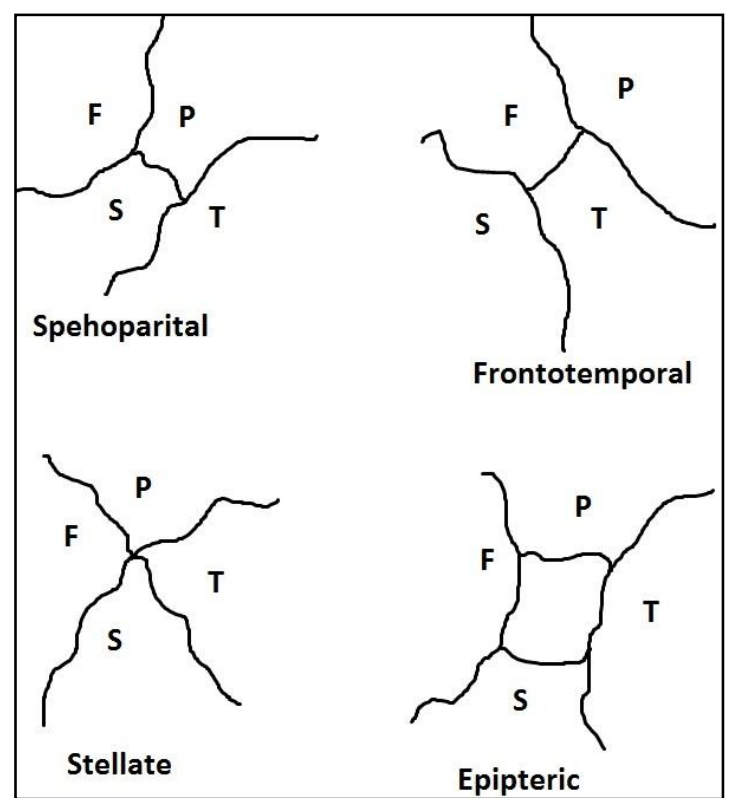

Fig. 1: Types of Pterion ( $F=$ Frontal, $P=$ Parietal, $\mathrm{S}=$ Sphenoid, $\mathbf{T}=$ Temporal)

\section{Result}

Morphology of pterion (Fig. 2-4)

We observed three types of pterion in 110 skulls. Most common type of pterion found to be sphenoparietal, was observed in 178 of total 220 pterion. Least common type of pterion observed to be Epipteric, was observed in 18 of total 220 pterion. Sphenoparietal, stellate and epipteric shows bilateral symmetry. Frontotemporal type of pterion was not found in any skull. Sphenoparietal was the most common type of pterion on both sides. Epipteric was the least common type of pterion on right side. Stellate was the least common type of pterion on left side. (Table 1)

Morphology of asterion. (Fig. 5)

Type 1 asterion was founded in 18 of total 220 asterion. Type II asterion was founded in 202 of total 220 asterion. Bilateral symmetry only found in type II. Type 1 did not show bilateral symmetry. (Table 2)

Table 1: Types of pterion in our study

\begin{tabular}{|l|c|c|c|c|c|c|c|c|}
\hline \multirow{2}{*}{ Pterion Pattern } & \multicolumn{2}{|c|}{ Right side } & \multicolumn{2}{c|}{ Left side } & \multicolumn{2}{c|}{$\begin{array}{c}\text { Bilateral } \\
\text { symmetrical side }\end{array}$} & \multicolumn{2}{c|}{ Total of both side } \\
\cline { 2 - 9 } & $\mathrm{N}=110$ & $\%$ & $\mathrm{~N}=110$ & $\%$ & $\mathrm{~N}=110$ & $\%$ & $\mathrm{~N}=220$ & $\%$ \\
\hline Sphenoparietal & 86 & 78.18 & 92 & 83.63 & 80 & 72.72 & 178 & 80.9 \\
\hline Frontotemporal & 00 & 00 & 00 & 00 & 00 & 00 & 00 & 00 \\
\hline Stellate & 18 & 16.36 & 06 & 5.4 & 06 & 5.4 & 24 & 10.9 \\
\hline Epipteric & 06 & 5.4 & 12 & 10.9 & 06 & 5.4 & 18 & 8.18 \\
\hline
\end{tabular}

Table 2: Types of asterion in our study

\begin{tabular}{|l|c|c|c|c|c|c|c|c|}
\hline \multirow{2}{*}{$\begin{array}{c}\text { Asterion } \\
\text { Pattern }\end{array}$} & \multicolumn{2}{|c|}{ Right side } & \multicolumn{2}{c|}{ Left side } & \multicolumn{2}{c|}{ Bilateral } & \multicolumn{2}{c|}{ Total of both side } \\
\cline { 2 - 8 } & $\mathrm{N}=110$ & $\%$ & $\mathrm{~N}=110$ & $\%$ & $\mathrm{~N}=110$ & $\%$ & $\mathrm{~N}=220$ & $\%$ \\
\hline Type I & 3 & 2.72 & 15 & 13.63 & 00 & 00 & 18 & 8.18 \\
\hline Type II & 107 & 97.27 & 95 & 86.36 & 92 & 83.63 & 202 & 91.18 \\
\hline
\end{tabular}

Table 3: Comparison of types of pterion

\begin{tabular}{|c|c|c|c|c|c|}
\hline & & & Pterion ( & & \\
\hline Study & Sample size & Spenoparietal & Frontotemporal & Stellate & Epipteric \\
\hline Murphy $^{6}$ & 388 & 73 & 7.50 & 18.50 & 1 \\
\hline Matsumura $\mathrm{G}$ et al..$^{10}$ & 614 & 79.10 & 2.60 & 17.7 & 0.60 \\
\hline Manjunath KY et al. ${ }^{11}$ & 172 & 93.55 & 3.52 & 2.93 & 17.30 \\
\hline Asala SA et al. ${ }^{12}$ & 212 & 82.1 & 23.6 & - & 5.7 \\
\hline Lee UY et al. ${ }^{13}$ & 149 & 76.5 & - & - & 40.3 \\
\hline Ersoy $\mathrm{M}$ et al. ${ }^{14}$ & 300 & 87.35 & 3.47 & 8.98 & 0.20 \\
\hline Saxena RC et al. ${ }^{15}$ & 203 & 84.72 & 10.01 & 5.17 & - \\
\hline Mwachaka PM et al. ${ }^{16}$ & 79 & 66 & 15 & 12 & 7 \\
\hline Hussain Saheb S et al. ${ }^{17}$ & 125 & 69.25 & 17.35 & 9.70 & 3.70 \\
\hline W Apinhasmit et al. ${ }^{18}$ & 268 & 81.20 & 1.10 & 0.40 & 17.40 \\
\hline $\begin{array}{l}\text { Mary Antony Praba et } \\
\text { al. }{ }^{19}\end{array}$ & 50 & 74 & 3 & 9 & 14 \\
\hline R. Sudha et al. ${ }^{20}$ & 150 & 80 & 3 & 5.30 & 11.30 \\
\hline Hariprasad et al..$^{21}$ & 60 & 89.20 & 3.30 & 5 & 2.50 \\
\hline Present study & 220 & 80.9 & - & 10.9 & 8.18 \\
\hline
\end{tabular}


Table 4: Comparison of types of asterion

\begin{tabular}{|l|c|c|c|}
\hline \multirow{2}{*}{\multicolumn{1}{c|}{ Study }} & \multirow{2}{*}{ Sample size } & \multicolumn{2}{c|}{ Asterion(\%) } \\
\cline { 3 - 4 } & & Type I & Type II \\
\hline Mwachaka $^{16}$ & 79 & 20 & 80 \\
\hline Hussain Saheb S $^{17}$ & 125 & 23.15 & 76.85 \\
\hline R. Sudha et al. $^{20}$ & 150 & 7.6 & 92.3 \\
\hline Gumusburun $^{22}$ & 302 & 9.92 & 90.08 \\
\hline Present study & 220 & 8.18 & 91.18 \\
\hline
\end{tabular}

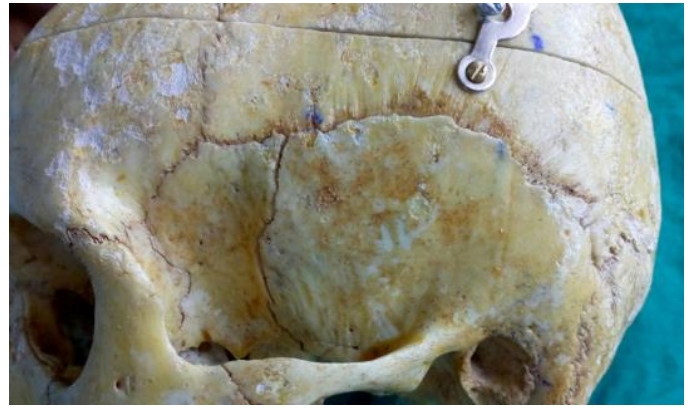

Fig. 2: Sphenoparietal type of pterion

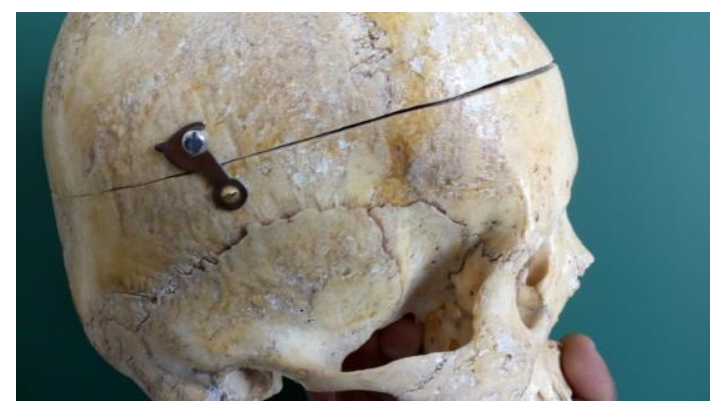

Fig. 3: Stellate type of pterion

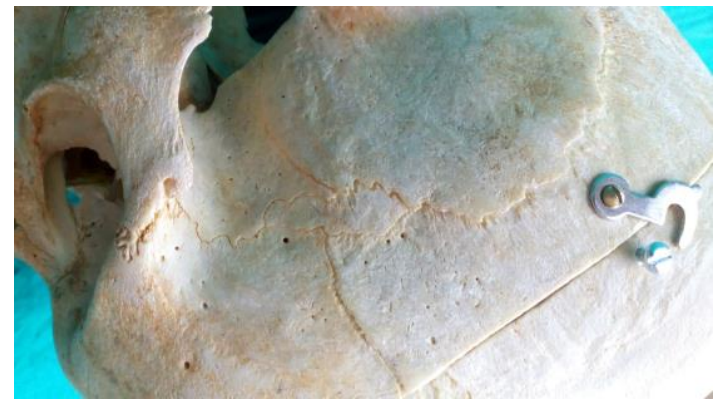

Fig. 4: Epipteric type of pterion

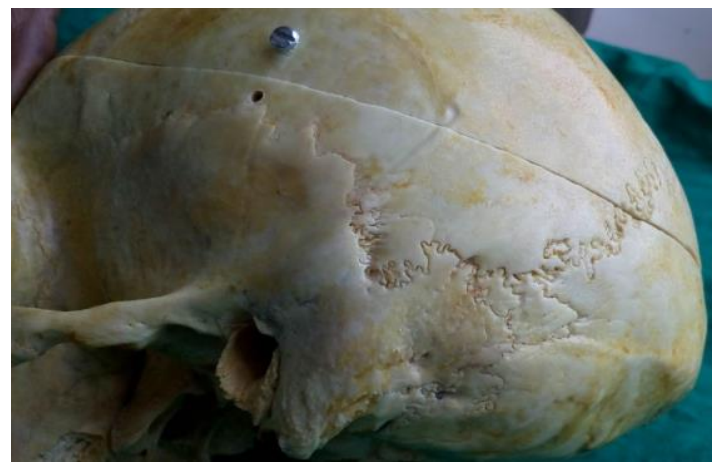

Fig. 5: Type I asterion

\section{Discussion}

In present study we observed three type of pterion - sphenoparietal, stellate, epipteric. In present study we did not observed frontotemporal type of pterion in any of skull. Table 3 shows comparisons of observation of present study with previous studies. Sphenoparietal was the most common type of pterion in present study, $80.9 \%$ among total pterion, which was in accordance with all previous study conducted by Murphy, ${ }^{6}$ Matsumura G et al., ${ }^{10}$ Manjunath KY et al., ${ }^{11}$ Asala SA et al., ${ }^{12}$ Lee UY et al., ${ }^{13}$ Ersoy $M$ et al., ${ }^{14}$ Saxena RC et al., ${ }^{15}$ Mwachaka PM et al., ${ }^{16}$ Hussain Saheb S et al., ${ }^{17}$ W Apinhasmit et al., ${ }^{18}$ Mary Antony Praba et al., ${ }^{19} \mathrm{R}$. Sudha et al. ${ }^{20}$ Hariprasad et al.. ${ }^{21}$ Sphenoparietal type of pterion was observed bilaterally in $72.72 \%$ and unilaterally in $27.27 \%$ of skull. Stellate was the second most common type of pterion in present study, 10.9\% of total pterion, which was in accordance with study conducted by Murphy, ${ }^{6}$ Matsumura G et al.,${ }^{10}$ Ersoy M et al., ${ }^{14}$ Hariprasad et al... ${ }^{21}$ In contrast to our observation, Asala SA et al., ${ }^{12}$ Lee UY et al. ${ }^{13}$ were not observed stellate type of pterion in their studies. Epipteric was the least common type of pterion observed in present study, $8.18 \%$ of total pterion. In contrast to our study Manjunath KY et al., ${ }^{11}$ Lee UY et al., ${ }^{13} \mathrm{~W}$ Apinhasmit et al., ${ }^{18} \mathrm{R}$. Sudha et al. ${ }^{20}$ observed epipteric as second most common type of pterion. Saxena RC et al. ${ }^{15}$ had not observed epipteric type of pterion in their study. Frontotemporal type of pterion was not observed in present study, which was in accordance with Lee UY et al. ${ }^{13}$

There were ethnic and regional variations in the pterion type. There are various factors which is responsible for skull suture growth by this they have effect on formation of different type of pterion. These may be due to genetic factors (MSX2 genehomeodomain transcription factor) and environmental factors. ${ }^{7}$ These variations may due to independent center ossification theory and genetic ${ }^{7}$ influence on the closure of skull sutures, by this they have impact on formation of various type of pterion. Genes play a crucial a role in craniofacial morphogenesis.

Most common type of asterion in our study was type II is $91.18 \%$ among total asterion. Same observation has been reported by Mwachaka, ${ }^{16}$ Hussain Saheb S, ${ }^{17}$ R. Sudha et al., ${ }^{20}$ Gumusburun ${ }^{22}$ Bilaterally type II asterion was founded in 101 skulls. Type I asterion found to be unilateral in all findings. The 
asterion has been used as a landmark in lateral approaches to the posterior fossa. It is not strictly reliable in terms of locating the underlying posterior fossa dura but it does lie directly over the transversesigmoid sinus complex. Caution must therefore be taken when placing burr-holes to avoid damage to the venous sinuses with potentially very serious consequences. $^{23}$

\section{Conclusion}

Our study has similar observation with previous studies done in India and internationally that sphenoparietal type of pterion is most common. Previous studies and present study have different observation for second and third most common type of pterion. For asterion also most common is type II was observed by all previous and present studies. Accessory bone or sutural bone alert radiologist and neurosurgeons while interpretation of $\mathrm{X}$-rays or surgically correcting a fracture. Observations of our study may be applicable with other commonly used method like radiological analysis for better prediction of different type of sutural morphology. Knowledge of sutural morphology may helpful for better surgical safety and efficacy.

\section{Reference}

1. Standring Susan, Gray's Anatomy-The Anatomical Basis of Clinical Practice. 41st ed. London, Elsevier Churchill Livingstone, 2016. pp.419.

2. Ma S, Baillie LJ, Stringer MD 2012 reappraising the surface anatomy of the pterion and its relationship to the middle meningeal artery. Clin Anat. 25(3):330-9.

3. Lang J. The pterion region and its clinically important distance to the optic nevre, dimensions and shape of the recess or the temporal pole. Neurochirurgia (Stuttg) 1984;27(2):31-35.

4. Moore, K. L. \& Dalley, A. F. Clinical Oriented Anatomy. 7th ed. Philadelphia, Lippincott Williams \& Wilkins, 2014. pp.874-875.

5. Broca, P. Instructions craniologiques et craniométriques. Mém Soc Anthrop Paris, 1875;2:1-203.

6. Murphy, T. The pterion in the Australian aborigine. Am J Phys Anthropol., 1956;14(2):225-44.

7. Wang, Q, Opperman, L. A, Havil L. M, Carlson, D. S. \& Dechow, P. C. Inheritance of sutural pattern at the pterion in Rhesus monkey skulls. Anat Rec A Discov Mol. Cell Evol Biol., 2006;288(10):1042-9.

8. Standring Susan, Gray's Anatomy-The Anatomical Basis of Clinical Practice. 41st ed. London, Elsevier Churchill Livingstone, 2016. pp.410

9. Sheng B, Lv F, Xiao Z et al 2012 Anatomical relationship between cranial surface landmarks and venous sinus in posterior cranial fossa using CT angiography. Surg Radiol Anat. 34(8):701-8.

10. Matsumura G, Kida K, Ichikawa R, Kodoma G. Pterion and epipteric bones in Japanese adults and fetuses with special reference to their formation and variations. Kaibagaku Zasshi. 1991;66(5):462-71.

11. Manjunath KY \& Thomas I.M., Pterion variants and epipteric ossicles in South Indian skulls, J Anat Soc India. 1993;42(2):85-94.
12. Asala SA, Mbajiorgu FE. Epigenetic variation in the Nigerian skull: sutural pattern at the pterion. East Afr Med J. 1996;73(7)484-6.

13. Lee UY, Park DK, Kwon SO, Paik DJ, Han SH. Morphological analysis of the pterion in Korean. Korean J Phys Anthropol. 2001;14(4):281-289.

14. Ersoy M, Evliyaoglu C, Bozkurt MC, Konuskan B, Tekdemir I, Keskil IS. Epipteric bones in the pterion may be a surgical pitfall. Minim Invasive Neurosurg. 2003;46(6):363-365.

15. Saxena RC, Bilodi AKS, Mane SS, Kumar A. Study of pterion in skulls of awadh area-in and around Lucknow. Kathmandu Univ Med J 2003;1(1)32-33.

16. Mwachaka PM, Hassanali J, Odula P. Sutural morphology of the pterion and asterion among adult Kenyans. Braz J Morphol Sci. 2009;26(1):4-7.

17. Hussain Saheb S, G.F. Mavishetter, S.T. Thomas, L. C. Prasanna, P. Muralidhar. Anatomical position of pterion among the Indian for lateral skull approach. Biomedicine 2010;30(3):391-393.

18. W. Apinhasmit, S. Chompoopong, V. Chaisuksunt, P. Thiraphatthanavong, and N. Phasukdee, Anatomical consideration of pterion and its related references in thai dry skulls for pterional surgical approach, Journal of the Medical Association of Thailand. 2011;94(2):205-214.

19. Mary Anatomy Praba and Venkatramaniah. Morphometric Study of different types of Pterion and It's relation with middle meningeal artery in dry skulls of Tamil Nadu. Journal of Pharmaceutical and Biomedical Sciences. 2012;21(21):1-4.

20. R. Sudha, C. Sridevi, M. Ezhilarasi. Anatomical variations in the formation of pterion and asterion in South Indian population. Int J Cur Res Rev, May 2013;05(09):92-101.

21. Hariprasad, NK Bezbaruah, Anushu Mishra, Parmatma Prasad Mishra. Morphometric analysis of pterion: A clinic-Anatomical study in North Indian dry skulls. Innovative journal of medical and health science. 2015;5(5):201-205.

22. Gumusburun, E., Sevim, A., Katkici, U., Adiguzel, E. And Gulec, E. A study of sutural bones in AnatolianOttoman skulls. International Journal of Anthropology, 1997;12(2):43-48.

23. Day JD, Tschabitscher M 1998 Anatomic position of the asterion. Neurosurgery. 42(1):198-9.

How to cite this article: Modasiya UP, Kanani SD. Study of pterion and asterion in adult human skulls of north Gujarat region. Ind J Clin Anat Physiol. 2018;5(3):.353-356. 